\title{
A LITERATURE REVIEW: WOMEN WORKER COMMUTING PRODUCTIVITY IN FORMAL SECTOR
}

\author{
Sylvia Vianty Ranita ${ }^{1}$ \\ Faculty Economic, Universiti Andalas, Indonesia \\ (Email: sylvia.ranita@gmail.com) \\ Fashbir Noor Siddin ${ }^{2}$ \\ Faculty Economic, Universiti Andalas, Indonesia \\ (Email: profashbir@gmail.com)
}

Accepted date: 27-01-2019

Published date: 08-07-2019

To cite this document: Ranita, S. V., \& Siddin, F. N. (2019). A Literature Review: Women Worker Commuting Productivity in Formal Sector. International Journal of Modern Trends in Social Sciences, 2(8), 23-31.

DOI: $10.35631 /$ IJMTSS.28003

\begin{abstract}
Woman worker has to get more attention in the formal sector of their role, beside of informal sector. Because of the women role has sufficient potentially toward the labor market. The number of commuter woman workers are getting increased in the formal sector. This is also influenced by the owner of the business to be trusted on the productivity of commuter woman workers. The urban sector of economic offers more formal sector especially service sector. Woman workers regarded more proper to be in formal sector that concerning to woman character for the reason of helping family economically, the concept of gender encourages woman workers to tend to have the spirit for doing work better. The effect of modernization has become one of mobilize to women in rural area to urban area even behavior or transportation. Conformity of woman characteristic informal sector encourages the productivity of workers in the service sector.
\end{abstract}

Keywords: Commuter, Formal Sector, Women Productivity

\section{Introduction}

The effect of economic structural changing takes influence to labor force, priority of women. The incoming of woman worker as labor force can take attention. The role of woman labors have significant progress in Indonesia, whereas labor force participation rate of woman are getting increase to $0,40 \%$ and labor force participation rate of men are getting decrease into 0,04\% (BPS Indonesia, 2018). In such away, increasing of labor force participation women labor is trusted to be able to encourage woman workers to fill in sector formal or informal. Hakim (2011) in rural area, decreasing of work opportunity in agriculture area has changed woman to view other sector especially service sector. Base on Labor Force Mobility in Indonesia 2018 state in service sector woman are regarded be able to develop their career As the progress of education level has driven the youth to be reluctant to work on agriculture sector and more interesting to get other sector. Referring to this matter young female labors who have education will be looking for work in urban area. 
The existing of formal sector in urban has driven labors to mobilize. International Labour Organization ILO, 2004 state that mobilization of labors is influenced by several factors as there is no compatibility chance for working and place with the location of work seeker live. (Andersson, Lavesson, \& Niedomysl, 2018) flexibility of economic bounded of how, where and when people work, then mobilization of labor can be facilitated and people in rural area are able to do commuter for work in urban area as the city is centre of career and work

Mobilization can happened because of suburban dependency to urban area. One of mobilization goals is for seeking job in meaning to increase welfare. (Jones, 1988) commuting of mobilize happened as the rill income has differential, work opportunity, infrastructure applied and interference of government toward decision of labor wage in industry, and also lack of investment in agriculture area. Those are caused by the opening of extensive work opportunity and high wage in urban area that are compared if they do not make mobilization. Warsida, Adioetomo, \& Pardede (2013) the worker who has work in formal sector tends to do commuting than those are working in informal sector.

The increase of commuter workers continues to grow and many are carried out by workers with secondary education who are able to fill employment opportunities in urban areas. Indonesia Statistik (2016) reported that commuting labors get increasing about 6,0\% in 2016. This raising was taken from 2012 about $5,7 \%$. It is noted in survey that commuting worker has $73,6 \%$ over high school education. Sakernas report in 2016 most of commuting women workers are younger than man commuting workers. Mobilization statistic and labor force Indonesia (BPS Indonesia, 2017) state that increasing number of commuting women labors from rural area in 2015 are about 320.352 becomes 391.246 in 2016. Based on above decription of commuting labors is showing that in formal sector role of commuting woman worker are quite a lot in labor market of Indonesia.

The increasing of woman worker in force participation rate and raising number of woman worker in formal sector has possibility of expectation towards working productivity such as education, skill, age and wage can meet the need of workers in urban area. Warsida et al.(2013) take Jabodetabek as object of research, the biggest commuting area in Indonesia, states that is found positive correlation between raising of wage to commuting even in certainty level, raising oppurtunity of commuting for male resulted of the raising wage smaller than commuting for woman. In case of wage is effect of woman does commuting mobilization.Pierrard (2008) decision to do trip is depending on labors productivity and perspective. Ignacio \& Molina, (2011) The general assumption in the urban economic literature is that private commuter costs are fully by workers and do not affect workers' productivity.

Some of the thoughts above lead to commuter workers, especially women who work in the formal sector have good productivity. The article aims to review several other studies regarding the impact of productivity of women workers commuting in the formal sector. This paper will explain about how the theoriticall and progress of woman labors productivity in commuting as formal sector workers. The review would be parted into section (1) introduction and phenomenom in Indonesia, section (2) definition of commuter theorically and empirical, section (3) describing productivity of woman labors and empirical verifying, section (4) closing which including conclusion and questions about productivity commuting woman labors in the formal sector and also exposes of how this matter can explore the knowledge of woman labors in the formal sector. 


\section{Literature Discussion}

\section{Commuter Definition}

At the begining commuter was known as short distance transportation which took person from and to city. Normally the person comes from the district of city. As the time process and city had development, commuter could be meant to a worker who had trip from where he/she is living around the city to the place of work in city. Sugianti \& Anggorodi, (2013) stated that commuter derived of word commutation that is a constant trip at suburban area of town to the centre of city for working destination. Indonesia had known commuter as "penglaju"

The idea to combinate of view from modernisation theoritical and demographic analyse of transtition, these ideas took hypothesize that people had passed 5 phases differential of development, it was from pre-modernisation traditional people to super future people, was followed by internal and international migration. This idea was the beginning of the emergence of the commuter. The commuter was conveyed by Wilbur Zllinski in 1971(Hypothesis et al., 2009) his ideas had got many criticizes, but this assumption was nearly undisputed in level of highest mobilisation pervasive and persuasive. Thus these ideas also explained that social modernisation was increasing of region migration and circulation of population. Zillinsky ideas implied that person mobilisation transition could happen because of many aspects in modernisation.

Commuter activities will be carried out by modern society and as a result of the increasing population that effect to choose between working place and residence. Lyons \& Chatterjee (2008) states that the term of commuter more about a routine and recuring trip concerning to transportation. The commuter action is reflecting of modern people, the commuter also has role to development and take impact to district. Activity of Person movement to increase welfare has created a thought that commuter is mobilisation. (Pooley, 2009) states that daily mobilisation is other aspect of population movement such as migration of long trip. Todays, some people has done longer trip as mobilisation than make a move to new home to close place of work. This is a social process, economic and family live function to hold the role, not only does to human geography in such away there's must be more complete explanation of other. Because of daily mobilisation for some people must be have relation to budget which effects to daily trip as the last of sicial function. The expense of mobilisation is personal budget and family, budget of social and culture, economy budget, government budget, and environtment budget. Sari \& Putrawan (2015) had parted people mobilization into permanent mobilization and non- permanent mobilisation. Permanent mobilisation is the movement of people permanently to the destination and while non-permanent mobilisation is in-constant movement. Permanent mobilisation are becoming two commuting and circulation in destination area. For commuting mobilisation, a study by Mantra in 1981 in Indonesia had definition that the people will return to their district on that day or in limit time of 6 hours or half day. Indrareni \& Ratnasari (2013) says that commuter is recuring trip where routine activity is done in short distance in a day. This activity is done by migrant for avoiding of staying at the destination. Therefore, the impact of the activities of commuter workers on the labor market will have an impact other than wages that can encourage increased labor force participation rates and the productivity.

Lan (2015) modernization is a changing and transformation process of life specified to traditional that have progressed into social, economic and politic paterns. The realization of modernize can be seemed through behaviour which are adopting modern aspects of life such as mechanism, migration, communication device usage, and good ordering bureaucracy of 
administration system. It is known that in Zelinsky hypothesis has good patern and ordering functionally, frequency, periodic, distance, rute, destination, level, and migrant clasification. Mobilisation of transition can be done even physically or social and possibility has technology changed. The progressing of commuter is not only in developes countries but also into Indonesia. BPS Indonesia(2017) explained that commuter is people mobilisation to leave for and back home from destination in about 24 hours by passing boundary of town administrative routinize. Someone who makes this routine trip to work by day and come back to his own town after working is called commuter worker. Base (Hugo, 2001)in Indonesia, was found the phenomenom of commuter got increasing in three last decades in Indonesia as consequently of massive changing toward social and economic sector in urban area.

Based on the report of people mobilisation and man power statistic 2016 was known increasing number of commuter labors in 2012 as many 5,7\% and in 2016 raised into 6,0\%. Beside of that the report of Sakernas 2016 declared about comparison of man commuter worker and woman commuter worker are similar. Therefore it would be interesting to discuss about the commuter labors progress to further. Statistik (2016) stated commuter worker depend on education. (Hasyasya \& Setiawan, 2012) a decision to be commuter workers from Kabupaten Kendal to Semarang, with binary logistic regression model analysis and the result of this research that the variable life and variable pay significantly influence the decision to commuter workforce and marital status and education level not significant influence on the decision to commuter workers. Warsida et al. (2013) commuting in Jabodetabek, with binary logistic regression and data Sakernas 2012, that male in formal sector are more likely to commute and the highest probability unmarried male to commute than female. But, the level of wage, an increase in wage increases probability to commute among male lower than probability to commute among female. Renauly (2014) the results showed that established young women and young men tended to work in the Jakarta, which is an office area, and the others tended to work in the suburban area. Cars are generally used by women and men with high income, choosing toll routes. Motors tend to be used by middle income men, with the middle route. Public vehicles tend to be used by women for long trips with middle income. (Yosritzal, Adji, \& Dissanayake, 2017) state productive and enjoyable activity of commuter workers to be less important to the passengers compared to other attributes such as ticket price, reliability seat and waiting room. Therefore most of research has been done concerning with the decision of commuter, education, trip patern, trip schedule usage and gender. Moreover, it is interesting to discusses about how woman commuter worker productivity.

\section{Woman Commuter Labors Productivity}

Woman worker productivity would be done better by priority reasoning of economic factor. This factor is one way to assist and increase family welfare and financial. Then this matter has decided by woman to find a work as they can do. Those are come from rural area, they tends to find informal sector for workiong as they do not have any special skill but on the other side those have skill will fill formal sector in service. The urban area has interesting ways to invite productiv worker from suburban. (Chapple \& Weinberger, 1996) the concentration of work in urban are is stronger to woman than male, $75 \%$ womans are having work in special industry such as hospital, school, insurance and finance, departement store, and house keeping service. The motivation of work is becoming their hope and expectation to find the work. (Hati, Irawati, \& Wirangga, 2014) intrinsic motivation significantly influences toward social economic matter of woman worker in industry sector. (Lan, 2015) states that woman have to posses a power in order to have high bargaining position then could make networking and confidence and personalize in economic, woman labors role in development will be important as the existing of technology, communication and information. 
Availability of work opportunity in urban area at formal sector, especially in service area be expected can give a chance to people who are working around their area for improving life economic and progresss their welfare by working in urban area. (Setyodhono, 2017) in Indonesia, most of commuter workers are woman in their productive age is about 20-30 years old. More easy for accessibility to urban area make mobilization of workers keep growing as technology, communication and information getting develop too.

Thinking that woman commuter workers has more productive in working, it becomes base measuring to define role of woman workers in formal sector. Ratih, \& Indriyani (2017) states that segmentation in age clasification showing real comparison between the ages of 15-24 to the age of 45 where the young woman worker is better than older woman workers in formal sector. Hati, Irawati (2015) the research is showing that (1) asumming that rising of work motivation in one unit of constant variable, then productivity of workers unit will increase in amount of 0,373 or $37,3 \%$ (2) productivity of work will increase in amount of 0,255 or $25,5 \%$ in each raising of one unit of dicipline, (3) unit of productivity will increase in amount of 0,323 in each raising of one unit of skill with asumming in constant variable. Skill variable of work (X3) has dominated toward productivity of woman worker in operator production department. Factor of woman skill in operator sector tends to influence of work production in manufacture industry Batamindo. The woman young workers can compete the male workers. The young woman workers has capability to have work in public sector. (Rendall, 2014) woman workers has higher productivity in service sector as this sector need no physic power and comfort area. The different of gender makes the wage can not depend totally on productivity. The changing condition is also conveyed by Macdonald (1999) states that during the last three (3) decades, position of woman has significant change in structuring of working area and family where they are living. More develop of urban area and increase education of woman that is possible for woman as workers in urban area. Beside that Macdonald (1999) give another states that woman in local labor market, come from rural area that working in urban which is not metropolitant can have shorter trip and then reduce costs of commuter than woman those are working in metropolitant. But, the chance which is offered by non-metropolitant labor market will decrease by movement of working into metropolitant in diversity. Renauly (2014) in Bekasi (Indonesia) states that the more of accessibility then woman workers commuter will move futher, but the lower accessibility then the shorter distance of woman workers commuter. Therefore, woman commuter worker in indonesia have high education and productive age which posibility be able to give good performance of work especially in formal sector of service.

The existing of formal sector has role to be able to push the economic growth of a country. Particularly in urban area which will be come advancing as the workers have already fulfilled and all formal sector are running as well as in service sector. (N. P. Sari, 2016) states that work transformation from informal sector to formal sector being expected to be progress to workers productivity, also encourage to economic growth of a country. The research related to productivity of woman commuter labors have been much studied such as (Stankovic, Makojevic, et al 2015) in researching the south part city of Serbia by resulted that there were positive relation between woman labors and business owner perception toward quality of labors. Whereas increasing of $1 \%$ woman labors can take effect to increase of working quality level in average as 0,439. Puigarnau \& Ommeren (2010) state that effect of distance more influence towards the offering of work for woman who makes commuting trip but it is only a bit effect, even most of woman has also working in city more often. Ommeren, Fosgerau (2009) states that there are positive relation between long distance and wage as it defines of net 
productivity labor - productivity is minus to wage - is negative function of budget commuter labor. It is also implied that business owner requested believe that woman productivity has no relation on rute. This case seems possibly more interesting in seeing corelation to the progress number of woman labors commuter as ensuring to have capability and good productivity. Shaw, (2005) adds there is influenced factor is from economic environment like the acceleration technology changing and high global compete, showing the woman has special quality in skill within company productivity. Having social networking for progressing of woman and company productivity. On other side, woman always has good way to build relation and keeping social networking at the company. Åslund, Blind, \& Dahlberg (2017) the job and wage are depends on industrialist capable in observate budget of his labors, in this matter as away to anticipate labors behaviour. Therefore women workers who conduct commuters can provide good work productivity through managerial skill, motivation dan social networking.

Working productivity measurement needs to be done to view of how significance the influence woman labors do commuting in relation taking micro decision by company towards woman labors those are doing commuter and in relation taking macro decision by government to define policy statement of woman minimum wage. it is done to reduce descrepancy gender between male and woman for wage payment. The measuring productivity of macro has studied most such as (Emre, 2015; Harriet \& Emmanuel, 2013; Somuyiwa, Fadare, \& Ayantoyinbo, 2015; Ommeren \& Fosgerau, 2009) taking measurement of productivity by seeing traffic congestion. (Modica \& Chansky, 2018) labors productivity will be counted by devide index urban transit systems output to working hours index. Other researcher Kreindler (2019) taking measurement of commuter labors productivity through celular function usage. The research in Indonesia on women's productivity is still limited to health such as: Sugianti \& Anggorodi (2013) on commuter workers in Jakarta stated that almost all commuter workers, experienced stress triggered by transportation and it shown through emotions and behaviors that impacted will be declining work productivity.

Yet, none of research that study about measurement productivity of commuter woman workers in formal sector in Indonesia, especially in economic study. There are big question to another research like how the effect distances of trip and productivity to women workers, how the effect of consumption and income to productivity woman worker and etc. This thing has to be made to see woman role contribution work in formal sector, particularly to woman does commuting. The role of woman in formal sector must have more attention, and not only is informal sector. It must be made to see that woman role is really potential in labor market. Therefore, by advancing of informal sector to formal sector to build sustainable development for human resources that impact toward economic progress in micro and macro scale. Additional, this must be attention of how informal and formal sector has tigh relation to interact in developing economic balance. Especially Indonesia that has undergone of economic structural changing.

\section{Discussion}

The advancing of city will be an interesting way to labors around the district of city. Where the city has given many oppurtunity of work in formal sector. The formal sector has been fulfilled by many woman labors those have skill and high education. International Labour Organization(Conference, 2014) says that mobilisation of labors happened because there is no point centre of where the oppurtunity location of work is keeping grow and to location of job seeker living. Woman labors in formal sector tends to do commuting. Beside that, the increasing number of woman to work in formal sector by doing commuting has good productivity in service area. Having trust by owner of business, head of institution states that 
woman has also good ethic of work beside their education and skill which are expecting to be able to enhance productivity and positive contribution for the participation in market labors. Therefore it is concluded that there are 3 (three) interesting things conveyed relating with woman commuter labors in formal sector that is (1) Urban economic sector offers more service sector than production or industry, (2) woman workers is more proper to have work in service sector than male workers as characteristic, (3) Concept of gender has put woman workers more enthusias working better, as the encourage of family economic or herself (4) moderenisation effect is one of mobilisation for woman in rural area to urban as transportation apply. Eventhough, there is no more related study to commuter labor productivity especially woman, therefore it is needed emphiricall discussion.

\section{References}

Andersson, M., Lavesson, N., \& Niedomysl, T. (2018). Rural to urban long-distance commuting in Sweden : Trends, characteristics and pathways. Journal of Rural Studies, 59(May 2017), 67-77. https://doi.org/10.1016/j.jrurstud.2018.01.010

Åslund, O., Blind, I., \& Dahlberg, M. (2017). Regional Science and Urban Economics All

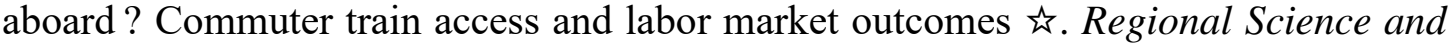
Urban Economics, 67(July 2016), 90-107. https://doi.org/10.1016/j.regsciurbeco.2017.08.007

BPS Indonesia, B. P. S. (2017). Statistik Mobilitas Penduduk dan Tenaga Kerja 2017.

BPS Indonesia, B. P. S. (2018). Keadaan Ketenagakerjaan Indonesia.

Chapple, K., \& Weinberger, R. (1996). Is Shorter Better? An Analysis of Gender, Race, and Industrial Segmentation in San Francisco Bay Area Commuting Patterns. Women's Travel Issues: Proceedings from the Second National Conference.

Conference, I. L. (2014). Transitioning from the informal to the formal economy (103rd Sess). Geneva: International Labour Office. Retrieved from https://www.ilo.org/wcmsp5/groups/public/---ed_norm/--relconf/documents/meetingdocument/wcms_218128.pdf

Emre, O. (2015). Commuting Related Problems In The Workplace. Journal of Business Studies Quarterly, 6(4). Retrieved from www.cyclescheme.co.uk,

Gutiérrez-i-Puigarnau, E., \& van Ommeren, J. N. (2010). Labour supply and commuting. Journal of Urban Economics, 68(1), 82-89. https://doi.org/10.1016/j.jue.2010.03.003

Harriet, T., \& Emmanuel, A. K. (2013). An Assessment of Traffic Congestion and Its Effect on Productivity in Urban Ghana. International Journal Of Business and Social Science, $4(3)$.

Hasyasya, N., \& Setiawan, A. H. (2012). Analisis Faktor - Faktor Yang Mempengaruhi Keputusan Tenaga Kerja Menjadi Commuter Dan Tidak Menjadi Commuter Ke Kota Semarang ( Kasus Kebupaten KENDAL ). Diponegoro Journal of Economic, 1(1), 110. Retrieved from http://ejournal-s1.undip.ac.id/index.php/jme

Hati, S. W., Batam, P. N., Irawati, R., \& Batam, P. N. (2015). Analisis Faktor-Faktor yang Mempengaruhi Produktivitas Tenaga Kerja Wanita Bagian Operator Produksi pada Industri Manufaktur di Kawasan Batamindo Batam. In Preceeding 3rd Applied Business and Engineering Conference 2015, ISSN 2339-2053. Batam.

Hati, S. W., Irawati, R., \& Wirangga, A. (2014). Motivasi Kerja Terhadap Kondisi Sosial Ekonomi Tenaga Kerja Wanita di Sektor Industri. In Preceeding Applied Business and Engineering Conference (ABEC).

Hugo, G. (2001). Population Mobility and HIV/AIDS in Indonesia. UNAIDS, Indonesia, ILO, Indonesia. Retrieved from http://www.hivdevelopment.org/pdf_files/2001-26 Population Mobility and HIV AIDS in Indonesia.pdf 
Hypothesis, T., Author, M. T., Source, W. Z., Review, G., Geographical, A., \& Stable, S. (2009). OCIAL scientists are guided in their gropings toward pattern and regu-, 61(2), 219-249.

Ignacio, J., José, G.-N., \& Molina, A. (2011). Commuting Time and Labour Supply: A Causal Effect?

Indrareni, A., \& Ratnasari, A. R. (2013). Pengaruh Pergerakan Pekerja Commuter Terhadap Pola Konsumsi Di Kecamatan KaliwungU Anindita Indrareni ${ }^{1}$ dan Anita Ratnasari $\mathrm{R}^{2}$ Mahasiswa Jurusan Perencanaan Wilayah dan Kota , Fakultas Teknik , Universitas Diponegoro Dosen Jurusan Perencanaan Wilayah dan Ko. JurnalTeknikPWK, 2(4), 927-937.

Jones, G. W. (1988). Urbanization Trends in Southeast Asia : Some Issues for Policy. Journal of Southeast Asian Studies, XIX, No.1(August 2009), 137-154. https://doi.org/10.1017/S0022463400000370

Kreindler, G. E. (2019). Measuring Commuting and Economic Activity inside Cities with Cell Phone Records *.

Lan, T. J. (2015). Perempuan dan modernisasi, 17(1), 17-28.

Lyons, G., \& Chatterjee, K. (2008). A human perspective on the daily commute: Costs, benefits and trade-offs. Transport Reviews, 28(2), 181-198. https://doi.org/10.1080/01441640701559484

Macdonald, H. I. (1999). Women's Employment and Commuting: Explaining the Links. Journal of Planning Literature (Vol. 13).

Modica, N. F., \& Chansky, B. (2018). Productivity in transit: a new measure of labor productivity for urban transit systems. Monthly Labour Review, US Bureau Of Labor Statistics, (August), 1-32.

Pierrard, O. (2008). Commuters, residents and job competition. Regional Science and Urban Economics, 38(6), 565-577. https://doi.org/10.1016/j.regsciurbeco.2008.04.003

Pooley, C. G. (2009). Mobility, History of Everyday, 144-149.

Ratih, A., Indriyani, A., Ratih, A., \& Indriyani, A. (2017). Segmentasi Pasar Tenaga Kerja Wanita Di Indonesia ( Berdasarkan Data Sakernas 2015 Semester II ), 8(1), 27-38.

Renauly, M. Pola Perjalanan Penglaju Kota Bekasi Ke Jakarta (2014).

Rendall, M. (2014). The Service Sector and Female Market Work *, (312), 1-35.

Sari, N. P. (2016). Transformasi Pekerja Informal ke Arah Formal : Analisis Deskriptif dan Regresi Logistik Informal Worker Transformation to Formal Sector : Descriptif and Logistic Regression Analyses. Jurnal Ekonomi Kuantitatif Terapan Vol. 9 No. 1, 9(1), 28-36.

Sari, Nindya Purnama, \& Putrawan, I. W. (2015). Mobilitas Non Permanen Menjadi Pilihan Sebagian Pekerja Dalam Menghadapi Himpitan Ekonomi Di Wilayah Denpasar , XI(2), 59-67.

Setyodhono, S. (2017). Faktor yang Mempengaruhi Pekerja Komuter di Jabodetabek Menggunakan Moda Transportasi Utama Several Factors that Affect Commuters in Jabodetabek use the Main Moda of Transportation to Place of Work. Warta Penelitian Perhubungan, 29(1), 21-32.

Shaw, K. (2005). Women's Contribution to Productivity: Women Have Been Key in Raising the Nation's Growth Rate, 45-48.

Somuyiwa, A. O., Fadare, S. O., \& Ayantoyinbo, B. B. (2015). Analysis of the Cost of Traffic Congestion on Worker's Productivity in a Mega City of a Developing Economy. International Review of Management and Business Research, 4(3), 644-656.

Stankovic, J., Makojevic, N., Jankovic-Milic, V., \& Radosavljevic, M. (2015). The female labour force in an urban economy during transition: A view from the City of Nis. Cities, 42(PA), 109-117. https://doi.org/10.1016/j.cities.2014.10.006 
Statistik, B. P. (2016). Analisis Mobilitas Tenaga Kerja. BPS Indonesia.

Sugianti, I., \& Anggorodi, R. A. (2013). Stres dan Strategi Coping pada Tenaga Kerja Komuter ( Penglaju ) Pengguna Transportasi Bus TransJakarta Tahun 2012. Fkm Ui.

Van Ommeren, J., \& Fosgerau, M. (2009). Workers' marginal costs of commuting. Journal of Urban Economics, 65(1), 38-47. https://doi.org/10.1016/j.jue.2008.08.001

Warsida, R. Y., Adioetomo, S. M., \& Pardede, E. L. (2013). Pengaruh Variabel SosioDemografis terhadap Mobilitas Ulang-Alik di Jabodetabek The Effect of SocioDemographic Variables on Commuting in Jabodetabek Pendahuluan, 13(2), 159-176.

Yosritzal, Adji, B. M., \& Dissanayake, D. (2017). Indonesian experience on travel time use onboard of commuter rail services. Transportation Research Procedia, 25, 2705-2716. https://doi.org/10.1016/j.trpro.2017.05.205 